\title{
Distance Learning Policy (PJJ) in the New Normal era in the Perspective of Urban Communities
}

\author{
Siti Alifah ${ }^{1}$, Ibnu Salman ${ }^{2}$, Agus Widodo ${ }^{3}$ \\ \{SitiAlifah_9913919007@mhs.unj.ac.id ${ }^{1}$, IbnuSalman_9913919012@mhs.unj.ac.id², AgusWidodo- \\ 9913919010@mhs.unj.ac.id ${ }^{3}$ \} \\ Pascasarjana $\mathrm{UNJ}^{1,2,3}$
}

\begin{abstract}
The Covid-19 pandemic which was declared by the Government of Indonesia as a national disaster in March 2020 made the world of education have to adjust the teaching and learning process from face-to-face to Distance Learning (PJJ). In the implementation of PJJ, digital technology is the key to the success of Distance Learning which can be a link between educators and students who are limited by distance. However, the existence of digital technology does not provide maximum benefits if it is not followed by mastery of digital technology by educators and students, the lack of availability of digital technology infrastructure as well as monitoring and evaluation from the Central Government and Local Governments so that the PJJ process can run as expected. Digital literacy is the ability to use technology and information from digital devices effectively and efficiently in various contexts, starting from device recognition, operation, processing and communication of information. Mastery of technology and digital literacy during a pandemic was able to facilitate communication and collaboration between educators and students, making PJJ more effective and accelerating the increase in digital literacy skills of students in the era of the Industrial Revolution 4.0. This research is an exploratory research using a qualitative approach. This study aims to explore broadly how the Distance Learning (PJJ) policy can be implemented well in schools / madrasahs in Bandung and urban communities as part of the organizers or providers of PJJ for their children, whether they are able to survive amid economic limitations, and how local government initiatives in bridging the PJJ problem.
\end{abstract}

Keyword: Distance Learning Policy, Urban Communities

\section{A. Introduction}

Since the beginning of 2020, the world has been shocked by nanometer-sized creatures, which are invisible to the naked eye but are very massive, can attack human breathing and cause death for patients with congenital diseases. The experts then gave the name Covid-19, short for Corona Virus Disease 19. Until now, Covid-19 has changed the order of life in all sectors of life, economy, social, culture, religion, without exception in the world of education.

Education is one of the central sectors affected by the Covid-19 pandemic. Until now, it is recorded that 156 countries in the world are changing their education policies, which originally used a face-to-face learning system to become a Distance Learning (PJJ) system. Indonesia also certainly does the same thing as other countries, namely changing the learning 
patterns of students from primary, secondary, to higher education by using distance learning (Syamsiah, 2020).

The implementation of education through distance learning has restarted after the 2020 class promotion holidays, but during the three months of the PJJ period, many obstacles were found, both for parents, teachers, and even students. According to the head of IGI (Indonesian Teacher Association), the problem is, among others, the lack of teachers' ability to use technological devices, at least this can be seen from the appearance of the impression of assignments by teachers through the WhatsApp application. PJJ using the Zoom, Google Meet, Jitsi Meet, and Webex applications are often constrained by unstable networks, not all students have laptops, not many students can access these applications, requiring teachers to be able to arrange their online classes in such a way. Another problem is that the majority of urban communities are migrants and their level of expertise is limited, sometimes due to economic limitations or limitations in mastering digital literacy, making it difficult to adapt to the policies of implementing PJJ. It is even found that in big cities such as Bekasi and Bandung, many parents are overwhelmed in helping the PJJ process for their children. If there is no maximum government intervention, this can be a problem in itself for the implementation of PJJ. It is as if the urban community is faced with a shock culture towards the implementation of PJJ, because it is not accompanied by good enthusiasm and mastery of technological literacy.

In response to this, the government issued a circular regarding the implementation of Distance Learning (PJJ). Through the circular of the Minister of National Education Number 4 of 2020 concerning Education Policy in the Covid-19 emergency period, the implementation of learning is in accordance with this policy which contains 4 things, namely (1) independent learning aimed at providing meaningful learning experiences without being burdened to complete curriculum achievements for class promotion and graduation; (2) students must be equipped with life skills about the Covid-19 pandemic; (3) the teacher assigns various assignments by considering differences in the abilities of each individual, and the learning facilities; and (4) providing feedback (feedback) on student performance must be qualitative.

However, implementing this policy is not as easy as turning your palms. There are still many things that cause the concept of Distance Learning (PJJ) to be less effective and efficient in its implementation. There are several obstacles that are felt by students and teachers, namely: first, there are technical problems that often occur, such as internet networks or server errors (Nurmukhametov et al., 2015). Second, in practicum subjects / courses, distance learning is not effective to be applied, lecturers/teachers only provide learning media in the form of practicum videos and steps for the work, but students do not do their own practicum. Third, the lack of a sense of responsibility for teachers in distance learning, this is evidenced in a survey which states that teachers consider that responsibility in traditional face-to-face teaching is generally higher than in distance education (Semradova \& Hubackova, 2016). Fourth, the inaccuracy of using learning media during distance learning, if the teacher does not vary the online learning media, students will get bored easily (Simbolon, 2014). In addition, other obstacles that are often found in the field are the lack of infrastructure (computer / laptop or smart phone devices, internet networks and quotas) in implementing PJJ owned by educators, students and student guardians; lack of mastery of the use of digital technology for educators, lack of readiness of educators in providing evaluation systems given to students, lack of public awareness of the concept of education, social and economic status margins are less able to adjust to the application of distance learning concepts 
that are thick with the use of technology, not to mention economic factors that squeeze most of the community due to this Covid-19 pandemic.

Several community initiatives to ease the quota burden in the implementation of Distance Learning (PJJ), free wifi has been opened in several community service offices, such as the Village Office, polici sector, there are even restaurant owners or business people who free wifi for students to participate in activities online learning during study hours, but this cannot be generalized because it is only local, not nationally comprehensive.

Distance learning (PJJ) is defined as a learning process where individuals have the opportunity to learn independently from time and place, using the methods and techniques used in learning activities (Kör et al., 2014) (Topalo, 2009). Distance learning is a learning activity in which students, teachers and teaching materials in separate locations are put together with the help of communication technology (Iskenderoglu et al., 2012) (Lenar et al., 2014). In distance learning (PJJ), teachers build online classes and use all internet technology suitable for student learning (Darmayanti et al., 2007) (Mittelmeier et al., 2019). Teachers should also create an effective learning environment in accordance with what has been planned beforehand, including technology in the learning process does not always guarantee students are motivated, therefore teachers need to build natural motivation for students because motivation will determine the intensity of students' learning efforts ElSeoud et al., 2014) (Handhika, 2012) (Dursun et al., 2013).

\section{B. Research Methods}

This research is an exploratory research using a qualitative approach. Exploratory research is research that aims to explore broadly about the causes or things that influence the occurrence of something (Arikunto, 2006: 7). This research is intended to explore broadly how the Distance Learning (PJJ) policy can be implemented well in schools / madrasahs in Bandung and urban communities as part of the organizer or provider of PJJ for their children, whether they are able to survive amid economic limitations, and how local government initiatives in bridging the PJJ problem.

Data collection techniques using interviews, observation, and documentation. Interviews were conducted with various related parties, namely the City Government of Bandung, the Education Office, West Java Provincial Office of the Ministry of Religion, the Ministry of Religion of the City of Bandung, MI / SD Heads of MI / SD, school / Madrasah committees, to explore the possibilities and constraints of PJJ in its implementation. Observations were made to see the readiness of facilities and infrastructure to support the PJJ process in an urban community. Documentation is carried out on various sources to identify opportunities for ICT utilization, such as the existence of Regional Regulations (Perda) which oblige teachers to master ICT in their learning. The data were analyzed using qualitative descriptive analysis.

\section{Results and Discussion}

Since the Indonesian Government announced the national coronavirus disaster (COVID-19) on March 14, local governments such as DKI Jakarta and several universities have changed face-to-face learning to Distance Learning (PJJ) so that teaching and learning activities can continue amid the pandemic that is being felt not only Indonesian people, but also the world 
community. The COVID-19 pandemic has a major effect on the world of education today, because large-scale social restrictions (PSBB) directed by the government require educational institutions to rapidly change their learning system to distance learning (PJJ) during this pandemic (Chick et al., 2020).

The learning process carried out online/online which is also known as Distance Learning (PJJ) is the right decision as an effort to break the chain of transmission of the Covid-19 outbreak, but still leaves several problems because the digital divide in Indonesia is still very high so not all students can get good quality learning through Distance Learning (PJJ). The reality is that education in Indonesia is still far from expectations, especially in relation to Distance Learning (PJJ). Almost some teachers at the primary and secondary education levels end up only giving a pile of assignments to work on questions from textbooks and worksheets and making material summaries without any prior explanation to students. The evaluation system is not clear, some send photos, videos to give assignments, some are not evaluated at all by the teacher.

This is what causes students to become overwhelmed, feel bored, and finally many students do not participate in implementing PJJ. Many educators forget the four basic policies of PJJ because they want to break through the practical path. Parents of students become overwhelmed when they have to assist their children in carrying out PJJ tasks that are too busy. It sounds ironic, on one hand everyone must maintain the safety of their souls from the threat of Covid-19, but on the other hand there are things to be sacrificed. In fact, education includes three things, namely integrating cognitive, affective, and psychomotor. Giving cognitive tasks to students is not enough, because students need socialization, need to play, and need to be happy. Even though during this pandemic there are limits that must be obeyed, at least don't overload students with piles of assignments that don't get feedback (Latip, 2020).

There are things that students need more during this pandemic than cognitive, namely values or life values, mindset and skills to eliminate boredom. One of the steps that can be taken to implement the four concepts of PJJ policies that do not burden students in their implementation is by implementing the team teaching program. For example, Indonesian and English teachers can collaborate with biology and chemistry teachers so that students make a project in the form of making tape / tempeh / seeding sprouts / making salted eggs. Through this one-time assignment, students will be able to make Indonesian and English assignments for procedural text material and carry out assignments for biology and chemistry subjects for fermentation systems and others (Latip, 2020).

Likewise with other subjects, for example, the Indonesian language assignment is integrated into the subjects of PKN, history and religion to make popular articles, make posters and so on. So besides students getting cognitive, students also get affective and psychomotor experiences in one task. As an evaluation, assignment submissions can take advantage of social media or other technological tools that can provide experience for students to participate in the development of the Industrial Revolution 4.0.

For educators as academics, with this pandemic period, they must review the ways of life by changing the face-to-face / close distance learning paradigm to distance learning with the concept of learning variations that do not bore students. Through the concept of Distance Learning (PJJ) and the use of digital technology in school-age children and students in Indonesia, it is hoped that they can study at home independently, overcome the limitations of distance learning proactively, creatively, innovatively, and improve practice skills. Therefore, educators and 
students must be creative and digitally responsive because digital technology is currently a basic need in all sectors of life, especially education.

According to Triwibowo (2020), the Ministry of Education and Culture needs to consider three vital aspects to ensure that the implementation of distance learning does not widen social disparities, deepens inequalities in the quality of education between socio-economic groups and makes marginalized groups more marginalized. The three digital aspects are the availability of digital infrastructure, digital skills, and technological characteristics.

\section{Availability of Digital Infrastructure}

Even though the government has issued a circular regarding the implementation of distance learning as an adjustment in the teaching and learning process in this pandemic era, currently Indonesia has not provided Information and Communication Technology (ICT) infrastructure as the main prerequisite for implementing distance learning, which is adequate and comprehensive. nationally. The latest International Telecommunication Union (ITU) and Central Bureau of Statistics (BPS) data illustrate that less than $40 \%$ of Indonesia's population is internet users, only $3 \%$ regularly get fast broadband internet access (Triwibowo, 2020).

Internet with broadband access is a vital component in PJJ because the learning method uses an audio-visual method that requires a large connection capacity. Jakarta, as the capital city of the country, not all of its people can enjoy a broadband internet connection, especially those who have not used an optical cable connection. Even though the majority of cellular phone operators in Indonesia already offer 4G LTE connections, the unstable signal quality is still an obstacle to the smooth running of the distance learning process. Although there is internet with fast access, not all people can afford this fast internet access.

According to the BPS (Central Bureau of Statistics) Indonesia Telecommunications Statistics (2018), in the last five years, the use of Information and Communication Technology (ICT) by households in Indonesia has shown rapid development. The percentage of the population using cellular phones continues to increase, until in 2018 it reached 62.41 percent. The growth in cellular phone use was also followed by growth in household ownership of computers and internet access, which reached 20.05 percent for computer ownership and 66.22 percent for household internet access. Internet use has also increased during the period 2014 to 2018, as indicated by the increase in the percentage of the population accessing the internet in 2014 by around 17.14 percent to 39.90 percent in 2018. Based on these data (only 20 Indonesians have computers, $05 \%$ ), is still classified as low, even though computers are an ideal tool for teaching and learning activities because the characteristics of computers allow the use of various applications that support the learning process, especially Distance Learning (PJJ). Economic factors are in fact still an obstacle to the use of computers in developing countries, including Indonesia, because people's purchasing power is still low.

\section{Digital skills: problems of students and teachers}

Distance Learning (PJJ) requires students and teachers to master qualified digital skills, because digital skills are another important factor in understanding the digital divide. Digital literacy and competence in operating computers and surfing in cyberspace are basic skills that must be mastered by students and teachers. Digital literacy was first defined by Paul Gilster (1997), namely the ability to understand and use information from various digital sources. Gilster 
defines that digital literacy is the ability to use technology and information from digital devices effectively and efficiently in various contexts, such as academics, careers, and everyday life. Meanwhile, Hague (2010: 2) argues that digital literacy is the ability to create and share in different modes and forms; to create, collaborate, and communicate more effectively, and understand how and when to use good digital technology to support those processes.

Prensky (2001), one of the originators of the digital natives generation theory, states the characteristics of digital natives, namely the generation born in the 1980s and afterwards, namely the generation born in the digital technology environment. It was explained that the digital natives generation is a generation with activities that are attached to the use of computers and consider digital technology to be an inseparable part of their lives. Another characteristic is that this generation really enjoys games (online games), as well as a need, a desire to always be connected to the internet at all times, creating content and sharing it with others, and being active in social media.

A study in the United States illustrates that digital skills are closely related to generation and age. The digital natives generation is considered to be more adaptive and skilled in using digital technology than their parents' generation. Teachers and lecturers who are not technology-savvy are less able to manage learning, resulting in a digital skill gap in Distance Learning (PJJ) because the generation gap correlates with digital skills.

However, social and economic status also affects students' digital skills. Students who come from underprivileged families likely do not have computers and internet access, so they experience limited physical access and digital technology materials. Even though they come from the digital native generation, the mastery of digital skills of students from underprivileged families will be lower than students from wealthy families. It can be concluded that the social/economic gap, the availability of access and digital skills are closely related and these three factors influence the success of the Distance Learning (PJJ) process, where the digital divide is a multidimensional problem that must be sought for a solution.

\section{Characteristics of Technology: Uncertainty in Technology Adoption}

Many alternative application choices that can be used in the Distance Learning (PJJ) process, for example Zoom, Google Classroom, Google Meet, Line, Whats App, and others require educators and students to understand the techniques of using each application that can affect interactions between participants students and educators. For example the Zoom application which is more interactive and has richer features will certainly provide more optimal results than the Whats App application. Educators must understand the characteristics of the applications used in Distance Learning (PJJ), especially related to knowledge of the advantages and disadvantages of the applications used. Preparation in making teaching materials will of course be adjusted to the capacities and capabilities of the applications used.

Based on Media Perfection Theory (media richness), face-to-face interactions are the richest media that can reduce ambiguity in message delivery. Digital media has limitations in providing non-verbal cues and also the speed of feedback that can interfere with communication during learning. Changes to face-to-face methods in class are mediated via laptop screens which require adaptation and changes, especially in terms of material preparation and interaction in cyberspace. Teachers who do not have sufficient digital skills and knowledge of the characteristics 
of technology will be hampered so that they cannot achieve the set learning objectives. This challenge is also experienced by students who are not familiar with the variety of learning applications that will be used. Limited economic resources create a digital divide among millennials, especially in the midst of an urban society, especially regarding the use of various applications (Triwibowo, 2020).

Students from middle and upper class families who have financial capacity are more able to explore with the internet and its applications than students from underprivileged families, so they are familiar and can quickly adapt to technology. Meanwhile, students from economically weak families can get left behind.

\section{Conclusion}

In a recent study by Jan van Dijk from the University of Twente, the Netherlands, on the digital divide, there is a link between social inequality and the availability of access to the internet and digital skills. Limited physical and material access to ICT among students from the middle to lower class has an impact on low competence and digital literacy which affects their ability to maximize the use of applications in PJJ. This allows PJJ to deepen social disparities (Triwibowo, 2020).

We cannot predict when the Covid-19 pandemic will end, so it requires formative evaluation during the Distance Learning (PJJ) process and solution steps are needed when there are indications that are not in line with expectations during the PJJ. The central and local governments in this case must oversee the Distance Learning (PJJ) process and provide the best solution for deficiencies, especially in terms of the availability of access to hardware (hardware), software (software), internet and digital skills so that the PJJ process runs as expected. and provide better learning outcomes than face to face.

Urban communities as part of the middle to lower class experience many obstacles related to PJJ policies for their children, the government seems not to know or is indifferent to this existence, so if it is left concerned about the transfer of knowledge or the process of social interaction in cyberspace in distance learning, it does not will produce good results because it is not supported by good policies either. 


\section{References}

[1] Chick, R. C., Clifton, G. T., Peace, K. M., Propper, B. W., Hale, D. F., Alseidi, A. A., \& Vreeland, T. J. (2020). ARTICLE IN PRESS Using Technology to Maintain the Education of Residents During the COVID19 Pandemic. Journal of Surgical Education. https://doi.org/10.1016/j.jsurg.2020.03.018 (diakses pada 19 Agustus 2020).

[2] Darmayanti, T., Setiani, M. Y., \& Oetojo, B. (2007). E-Learning pada pendidikan jarak jauh: konsep yang mengubah metode pembelajaran di perguruan tinggi di Indonesia. Jurnal Pendidikan Terbuka Dan Jarak Jauh, 8 .

[3] Dursun, T., Oskayba, K., \& Gökmen, C. (2013). The Quality Of Service Of The Distance Education. 103, 1133-1151. https://doi.org/10.1016/j.sbspro.2013.10.441 (diakses pada 16 Agustus 2020).

[4] Gilster, P. (1997). Digital Literacy. New York: Wiley.

[5] Hague, Cassie dan Sarah Payton. 2010. "Digital Literacy Across the Curriculum: a Futurelab Handbook. United Kingdom" dalam https://www.nfer.ac.uk/publications/FUTL06/ FUTL06.pdf, diakses pada 20 Agustus 2020 (diakses pada 18 Agustus 2020).

[6] Handhika, J. (2012). Efektivitas media pembelajaran im3 ditinjau dari motivasi belajar. Jurnal Pendidikan IPA Indonesia, 1(2), 109-114. https://doi.org/10.15294/jpii.v1i2.2127 (diakses pada 20 Agustus 2020).

[7] Iskenderoglu, M., Aydogdu, T., \& Palanci, M. (2012). Opinion of teaching staff in distance education systems , regarding the assessment and evaluation process. 46. https://doi.org/10.1016/j.sbspro.2012.06.314 (diakses pada 19 Agustus 2020).

[8] Kör, H., Aksoy, H., \& Erbay, H. (2014). Comparison of the Proficiency Level of the Course Materials (Animations, Videos, Simulations, E-Books) Used In Distance Education. Procedia-Social and Behavioral Sciences, 141. https://doi.org/10.1016/j.sbspro.2014.05.150 (diakses pada 16 Agustus 2020)

[9] Latip, Abdul. (2020). Peran Literasi Teknologi Informasi dan Komunikasi pada Pembelajaran Jarak Jauh di Masa Pandemi Covid-19. EduTeach : Jurnal Edukasi dan Teknologi Pembelajaran, Volume 1, No.2 Edisi Juni

2020.

https://www.researchgate.net/publication/341868608_PERAN_LITERASI_TEKNOLOGI_INFORMASI_D AN_KOMUNIKASI_PADA_PEMBELAJARAN_JARAK_JAUUH_DI_MĀSA_PANDEMI_COVID-19 (diakses pada 20 Agustus 2020).

[10] Lenar, S., Artur, F., Ullubi, S., \& Nailya, B. (2014). Problems And Decision In The Field Of Distance Education. Procedia - Social and Behavioral Sciences, 131(904). https://doi.org/10.1016/j.sbspro.2014.04.088 (diakses pada 18 Agustus 2020).

[11] Mittelmeier, J., Rienties, B., Rogaten, J., \& Gunter, A. (2019). International Journal of Intercultural Relations Internationalisation at a Distance and at Home: Academic and social adjustment in a South African distance learning context. International Journal of Intercultural Relations, 72(June). https://doi.org/10.1016/j.ijintrel.2019.06.001 (diakses pada 20 Agustus 2020).

[12] Nurmukhametov, N., Temirova, A., \& Bekzhanova, T. (2015). The Problems of Development of Distance Education in Kazakhstan. Procedia - Social and Behavioral Sciences, 182, 15-19. https://doi.org/10.1016/j.sbspro.2015.04.729 (diakses pada 20 Agustus 2020).

[13] Prensky, M.,(2001). Digital natives, digital immigrant. On the Horizon,9(5).Retrieved from http://www.marcprensky.com/writing/Prensky\%20\%20Digital\%20Natives, \%20Digital\%20Immigrants\%20\%20Part1.pdf (diakses pada 20 Agustus 2020).

[14] Samir Abou El-Seoud, M., Taj-Eddin, I. A. T. F., Seddiek, N., El-Khouly, M. M., \& Nosseir, A. (2014). E-learning and students' motivation: A research study on the effect of e-learning on higher education. International Journal of Emerging Technologies in Learning, 9(4), 20-26. https://doi.org/10.3991/ijet.v9i4.3465 (diakses pada 19 Agustus 2020).

[15] Semradova, I., \& Hubackova, S. (2016). Teacher Responsibility in Distance Education. 217, 544-550. https://doi.org/10.1016/j.sbspro.2016.02.042 (diakses pada 19 Agustus 2020). 
[16] Simbolon, N. (2014). Faktor-faktor yang mempengaruhi minat belajar peserta didik. Elementary School Journal Pgsd Fip Unimed, 1(2). https://doi.org/10.24114/ESJPGSD.V1I2.1323 (diakses pada 18 Agustus 2020).

[17] Statistik Telekomunikasi Indonesia. (2018).

https://www.bps.go.id/publication/2019/12/02/6799f23db22e9bdcf52c8e03/statistik-telekomunikasiindonesia-2018.html (diakses pada 16 Agustus 2020).

[18] Topalo, M. (2009). Distance education applications in concept acquisition for disabled individuals / special education for handicapped. 1. https://doi.org/10.1016/j.sbspro.2009.01.180 (diakses pada 18 Agustus 2020).

[19] Triwibowo, Whisnu. (2020). Gagap 3 aspek vital: kuliah online di tengah COVID-19 bisa perparah gap akses pembelajaran bermutu bagi mahasiswa miskin. https://theconversation.com/gagap-3-aspek-vitalkuliah-online-di-tengah-covid-19-bisa-perparah-gap-akses-pembelajaran-bermutu-bagi-mahasiswa-miskin134933 (diakses pada 19 Agustus 2020). 